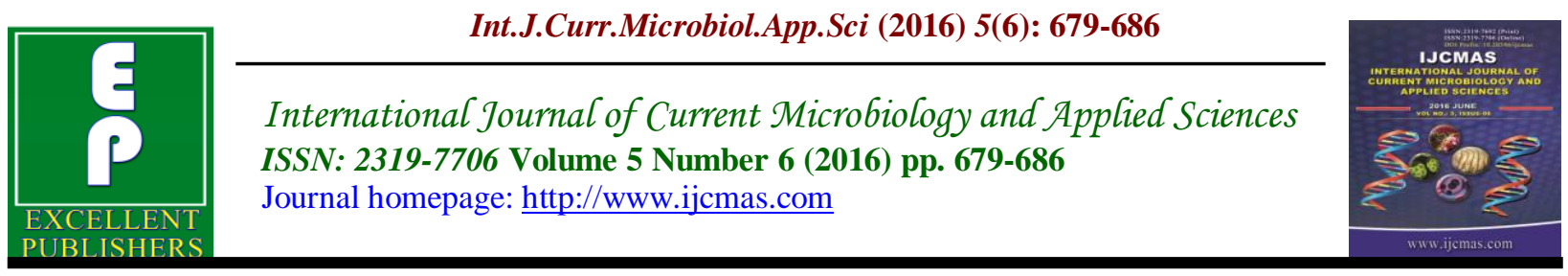

Original Research Article

http://dx.doi.org/10.20546/ijcmas.2016.506.074

\title{
Comparative Evaluation of Phytochemicals in Methanolic and Ethanolic Leaf Extracts of Anticancer Paradise Tree Simarouba glauca DC
}

\author{
Ashwani Kumar*, Vishwa Rawat, Amardeep and Vikas Kumar \\ Faculty of Biosciences, Shri Ram College \\ Muzaffarnagar, UP-251001, India \\ *Corresponding author
}

\begin{tabular}{|c|c|}
\hline & A B S T R A C T \\
\hline $\begin{array}{l}\text { Ke y w o r d s } \\
\text { Simarouba } \\
\text { glauca, } \\
\text { Laxmi taru, } \\
\text { Soxhlet extraction, } \\
\text { phytochemicals, } \\
\text { TLC. }\end{array}$ & \multirow{3}{*}{$\begin{array}{l}\text { Various medicinal plants have been used for years in daily life against diseases, } \\
\text { whole over the world. Presently herbs are used as important materials in the health } \\
\text { care system, create an herbal regeneration, spread with a superior speed throughout } \\
\text { the world. In Our current research work the Methanolic and Ethanolic extracts of } \\
\text { the leaves of Simarouba glauca were prepared with the help of simple extraction } \\
\text { and by soxhlet extraction. The extracts were used to detect the presence of different } \\
\text { phytochemicals like alkaloids, phenols, flavonoids, tannin, lignin, steroids, } \\
\text { glycosides, saponins, terpenoides and anthraquinone with their biochemical tests } \\
\text { and their conformation was done with the help of Thin Layer Chromatography } \\
\text { (TLC). It was seen that the methanolic extracts yielded higher amount of } \\
\text { phytochemicals in comparison to ethanolic extracts of S. glauca. }\end{array}$} \\
\hline Article Info & \\
\hline $\begin{array}{l}\text { Accepted: } \\
\text { 24 May } 2016 \\
\text { Available Online: } \\
\text { 10 June } 2016\end{array}$ & \\
\hline
\end{tabular}

\section{Introduction}

Use of plant as a source of medicine has been an ancient practice and is important component of the health system in India. Plants have been studied on the basis of clearly defined biological parameters like taste, metabolic property, quality, biological effect and potency. The corroborative and toxic plants are generally known to prevent aging, increasing longitivity and offer resistance to diseases by augmenting the immune system (Singh et al., 2001). To study phytochemical constituents Simrouba Glauca, paradise tree also known as Laxmi taru plant was selected. It belongs to family Simaroubaceae, which is a rainfed waste land evergreen edible oil tree up to 40-50 feet in height and spreads around 25-30 feet (ICRAF Agroforestry Tree Database, 2007 http://ecocrop.fao.org/ecocrop/srv/en/cropVi ew? $\mathrm{id}=9785$ ). It is used in many areas such as :

\section{Source of Biodiesel and Biofuel}

Simrouba seeds contain $60-70 \%$ oil that can be easily refined, bleached, deodorized and fractionated. Oil is obtained from seeds of Simrouba tree (Jena, P. C., et al., 2010). S. glauca is considered for biofuel production (Azam, M., et. al., 2005). Joshi and Joshi reviewed the application of $S$. glauca seed oil and pulp. They speculated that filtered 
crude oil can be used to blend with diesel at 5-10 \% while the surplus oil produced can be subjected to transesterification to manufacture biodiesel, a $100 \%$ substitute for diesel ( 1000-2000kg/ha/yr).

\section{Source of vegetable oil}

The oil is extracted from seeds in existing oil mills and processed by adopting conventional methods. Monseur and Motte reported that the seeds of $S$. glauca are rich in edible fat (nearly $60 \% \mathrm{~W} / \mathrm{W}$ ) that is used for cooking in tropical countries. The solid fraction rich in steric acid and palmitic acids can be used as coco-butter substitutes (CBS) or coco-butter extenders in confectionary and bakery industries (Jeyarani, T., Reddy, S. Y., 2001).Fruit is good source of vegetable oil which is rich source of fat soluble vitamins like $\mathrm{A}$ and $\mathrm{E}$ (Panhwar et al., 2007).

\section{Timber}

The wood is light, attractively grained, moderately strong generally less preferred by wood eating insects hence useful in making yolk for oxen, light furniture, toys, packing material, pulp for paper industry and match boxes. Waste wood is good fuel (Joshi and Joshi; http://ageconsearch. umn.edu/bitstream/43624/2/Simarouba\%20b rochure, \%20UAS\%20Bangalore,\%20India.p df), (Panhwar, (http://farzanapanhwar. blogspot.com/2007/08/simarouba-glauca-anew-forest-plantin.html.2007).

\section{Phytoremediation}

In general, soil adjacent to female $S$. amara trees had higher extractable phosphorus levels than soil adjacent to male trees or the control samples. This indicates that $S$. amara influence soil $\mathrm{pH}$ and tree gender has an additional influence (Rhoades, C. C., et al., 1994).

\section{Anticancerous}

Bioassay of Simarouba glauca resulted in the isolation of one new canthine glucopyranoside (1), seven known canthine alkaloids (2-8), two known quassinoids (910) and a neo lignin (1). Most of the compounds inhibited the proliferation of an Nf1 and p53 deficient mouse glioma cell line at non cytotoxic concentrations (Devkota KP et al., 2014). The cytotoxic and antileukemic activities of extracts of this plant are due to glaucarubinone (Ghosh PC, et al., 1977). F) Phytoremediation-Removal of toxic $\mathrm{Cr}(\mathrm{VI})$ in aqueous medium was investigated using activated carbon adsorbants prepared from the seed shells of Simarouba glauca. The removal of $\mathrm{Cr}(\mathrm{VI})$ was around $97 \%$ whereas other adsorbants showed much lower activities (Neelavathi et al., 2004). Pathology- Generally cattle and goats do not browse on Laxmitaru. It has no major pests and diseases are recorded at present in its native and also under Indian conditions (Armour, R. P., 1959).

\section{Materials and Methods}

\section{Preparation of extracts}

Leaves of Simarouba glauca were collected (during March to June), cleaned, dried and made into powder with the help of blender. Methanolic and ethanolic soxhlet extracts were prepared by dissolving $3 \mathrm{gm}, 5.07 \mathrm{gm}$ powder in $250 \mathrm{~mL}$ methanol and $250 \mathrm{~mL}$ ethanol respectively, followed by heating at $60{ }^{\circ} \mathrm{C}$ for $12 \mathrm{hrs}$.

Simple methanolic and ethanolic extracts were prepared with the help of dissolving $1.80 \mathrm{gm}$, $3.82 \mathrm{gm}$ powder in $40 \mathrm{~mL}$ methanol and $100 \mathrm{~mL}$ ethanol respectively, followed by heating at $60^{\circ} \mathrm{C}$ for $9 \mathrm{hrs}$. 


\section{Primary Screening of Secondary Metabolites}

Shade dried leaves were powdered using mixer grinder and subjected to soxhlet extraction with petroleum ether, chloroform, 95\% ethanol and distilled water for $18 \mathrm{hrs}$ in the order of increasing polarity. Extracts were used to detect the presence of secondary metabolites like alkaloids by mixing $2 \mathrm{~mL}$ of extract with $1 \% \mathrm{HCl}$, followed by boiling and treatment with 6 drops of Mayer's reagent (Chhetri, 2008 ; Parekh, 2007; Evans, 1989), presence of phenol was detected by phenol and ellagic acid test (Mallikharjuna, 2007, Dey \& Harbour, 1987, Evans, 1989), flavonoids by Alkaline reagent test (Mallikharjuna, 2007, Dey \& Harbour, 1987, Evans, 1989) and flavonoid test (Mallikharjuna, 2007, Dey \& Harbour, 1987, Evans, 1989), tannin by mixing crude extract with $2 \mathrm{~mL}$ of $2 \% \mathrm{FeCl}_{3}$ solution (Mallikharjuna, 2007, Chhetri, 2008, Doss, 2009), lignin by treating crude extract with $2 \mathrm{~mL}$ of furfuraldehyde (Mallikharjuna, 2007, Dey \& Harbour, 1987, Evans, 1989), steroids by Salkowski's test (Mallikharjuna, 2007, Dey \& Harbour, 1987, Evans, 1989), glycosides by mixing crude extract with $2 \mathrm{~mL}$ of glacial acetic acid containing 1-2 drops of $2 \%$ sol of $\mathrm{FeCl}_{3}$ followed by addition of $2 \mathrm{~mL}$ of $\mathrm{H}_{2} \mathrm{SO}_{4}$ (Krishnaiah, 2009; Edeoga, 2005; Doss, 2009), saponins by shaking the crude extract with water (Dey \& Harbour, 1987; Evans, 1989), tepenoides by Salkowski test (Rajasekariah et al., 1991) and anthraquinone by mixing the crude extract with $2 \mathrm{~mL}$ of chloroform and conc. $\mathrm{H}_{2} \mathrm{SO}_{4}$.

\section{Confirmatory test by TLC}

Presence of secondary metabolites was confirmed with the help of Thin Layer Chromatography (TLC) performed on Merck Silica Gel 60 glass plate using different effluent. The chromatograms were observed in UV/VIS before and after processing with spraying agent. Six solvent system were applied

a) Alkaloids-solvent system- Chloroform: Methanol (15:1)

b) Phenol- solvent system- Chloroform: Methanol (27:3)

c) Flavonoids- solvent system- Water: EtOAC (10:1)

d) Steroids- solvent system- Chloroform: Glacial acetic acid: Methanol: Water (64:34:12:8)

e) Glycosides- solvent system- EtOAC: $\mathrm{MeOH}$ : Water (80:10:10)

\section{Results and Discussion}

Phytochemicals are secondary metabolites in one or more parts of the medicinal plants. These have the ability to produce a definite physiological action on human body. In the present study, methanolic and ethanolic leaf extracts were isolated from leaf tissue of using simple and soxhlet extraction methods. Extracts were named A, B, C and $\mathrm{D}$ according to extraction methods and alcohol used for isolation of extracts.

It was clearly seen that the yield of Soxhlet extracts was more than Simple extracts. This conforms that Soxhlet extraction method is better than simple extraction method for isolation of methanolic and ethanolic extracts from Simarouba glauca leaf tissue. Leaf extracts obtained by different methods were analyzed for the presence of secondary metabolites such as alkaloids, flavonoids, phenols, Steroids, Glycosides, Saponins, Tannin, Steroid, Lignin, Saponin, Anthraquinone, and Terpenoid. For this different tests were performed. Alkaloids, flavonoids, phenols, steroids, glycosides, tannin, steroid, lignin and terpenoid were found to be present in all four samples. Saponin and anthraquinone were found to be absent. 
Table.1 List of tests used for detection of secondary metabolites

\begin{tabular}{|c|c|c|}
\hline Sr. No & Phytochemical Name & Reagent Used \\
\hline 1. & Alkaloid & $\begin{array}{l}\text { Mayer's reagent } \\
\text { Hagar's reagent }\end{array}$ \\
\hline 2. & Phenol & $\begin{array}{l}\text { i) } 2 \mathrm{~mL} \text { crude extract mixed with } 2 \% \text { solution of } \mathrm{FeCl}_{3} \\
\text { ii) Crude extract mixed with few drops of } 5 \% \text { mixture } \\
\text { of glacial acetic acid and } 5 \% \text { mixture of sodium } \\
\text { nitrate solution }\end{array}$ \\
\hline 3. & Flavonoid & $\begin{array}{l}\text { i) } 2 \mathrm{~mL} \text { crude extract treated with } 2 \% \text { solution of } \\
\mathrm{NaOH} \\
\text { ii) } 5 \mathrm{~mL} \text { of dilute ammonia solution added to aqueous } \\
\text { filterate of plant extract followed by addition of conc } \\
\mathrm{H}_{2} \mathrm{SO}_{4}\end{array}$ \\
\hline 4. & Tannin & $2 \mathrm{~mL}$ crude extract with $2 \%$ sol of $\mathrm{FeCl}_{3}$ \\
\hline 5. & Lignin & Extract with $2 \%$ furfuraldehyde \\
\hline 6. & Steroid & $\begin{array}{l}\text { Crude extract with } 2 \mathrm{~mL} \text { chloroform, conc } \mathrm{H} 2 \mathrm{SO} 4 \text {, } \\
\text { shaken gently }\end{array}$ \\
\hline 7. & Glycosides & $\begin{array}{l}\text { Crude extract }+2 \mathrm{~mL} \text { glacial acetic acid }+1-2 \text { drops of } \\
2 \% \text { solution of } \mathrm{FeCl}_{3} \text { Poured } 2 \mathrm{~mL} \text { of conc } \mathrm{H}_{2} \mathrm{SO}_{4}\end{array}$ \\
\hline 8. & Saponin & Crude extract $+5 \mathrm{~mL} \mathrm{dw}$, shaken \\
\hline 9. & Anthraquinone & $\begin{array}{l}2 \mathrm{~mL} \text { extract }+2 \mathrm{~mL} \text { of } 25 \% \text { ammonia sotution, shake } \\
\text { well }\end{array}$ \\
\hline 10. & Terpenoid & Extract $+2 \mathrm{~mL}$ chloroform $+1 \mathrm{~mL}$ conc. $\mathrm{H}_{2} \mathrm{SO}_{4}$ \\
\hline
\end{tabular}

Table.2 Yield of Methanolic and Ethanolic extracts using simple and soxhlet extraction methods

\begin{tabular}{|l|l|l|}
\hline Name of method & Yield of Methanolic extract & Yield of Ethanolic extract \\
\hline Simple extraction & $0.24 \%(\mathrm{~A})$ & $0.36 \%(\mathrm{C})$ \\
\hline Soxhlet extraction & $0.79 \%(\mathrm{~B})$ & $0.69 \%(\mathrm{D})$ \\
\hline
\end{tabular}


Table.3 Phytochemical constituents of Simarouba glauca sample A, B, C, D are as follows

\begin{tabular}{|c|c|c|c|c|c|c|}
\hline $\begin{array}{l}\text { Sr. } \\
\text { No }\end{array}$ & $\begin{array}{l}\text { Phytochemica } \\
\text { I Name }\end{array}$ & Observations & $\mathbf{A}$ & $\mathbf{B}$ & $\mathbf{C}$ & $\overline{\mathbf{D}}$ \\
\hline 1. & Alkaloid & $\begin{array}{l}\text { Creamish } \\
\text { precipitate/Brownish red } \\
\text { precipitate }\end{array}$ & ++ & ++ & + & +++ \\
\hline 2. & Phenol & $\begin{array}{l}\text { Blue green or black } \\
\text { coloration } \\
\text { Muddy yellow, olive } \\
\text { brown, niger brown or } \\
\text { deep chocolate colour }\end{array}$ & ++ & ++ & + & $\begin{array}{l}++ \\
+++\end{array}$ \\
\hline 3. & Flavonoid & $\begin{array}{l}\text { Intense yellow } \\
\text { Yellow coloration }\end{array}$ & $\begin{array}{l}++ \\
++\end{array}$ & $\begin{array}{l}++ \\
+++\end{array}$ & $\begin{array}{l}++ \\
++\end{array}$ & $\begin{array}{l}++ \\
++\end{array}$ \\
\hline 4. & Tannin & $\begin{array}{l}\text { Blue green or black } \\
\text { coloration }\end{array}$ & ++ & ++ & + & ++ \\
\hline 5. & Lignin & Red colour & ++ & ++ & + & + \\
\hline 6. & Steroid & Reddish brown colour & ++ & +++ & +++ & +++ \\
\hline 7. & Glycosides & Brown ring at interphase & +++ & ++ & ++ & +++ \\
\hline 8. & Saponin & No reaction & - & - & - & - \\
\hline 9. & Anthraquinone & No reaction & _- & $\ldots$ & - & _- \\
\hline 10. & Terpenoid & $\begin{array}{l}\text { Reddish brown colour on } \\
\text { interphase }\end{array}$ & ++ & ++ & ++ & ++ \\
\hline
\end{tabular}

Fig.1 TLC of Alkaloides

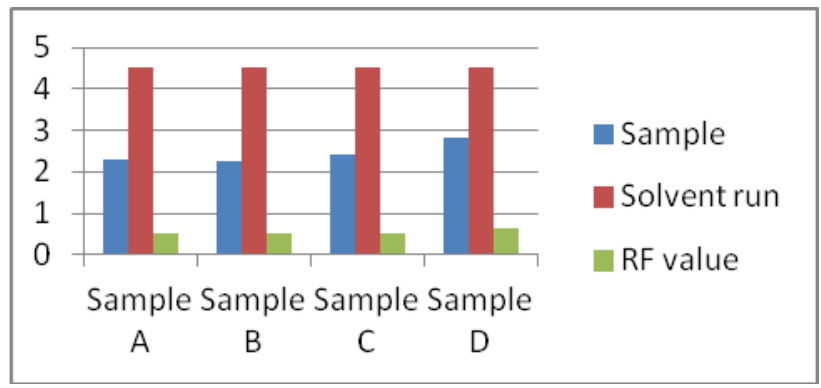

Fig.2 TLC of Phenols

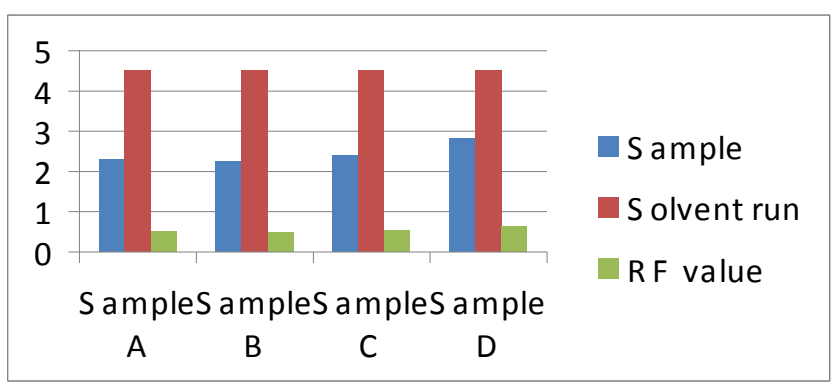


Fig.3 TLC of Flavonoids

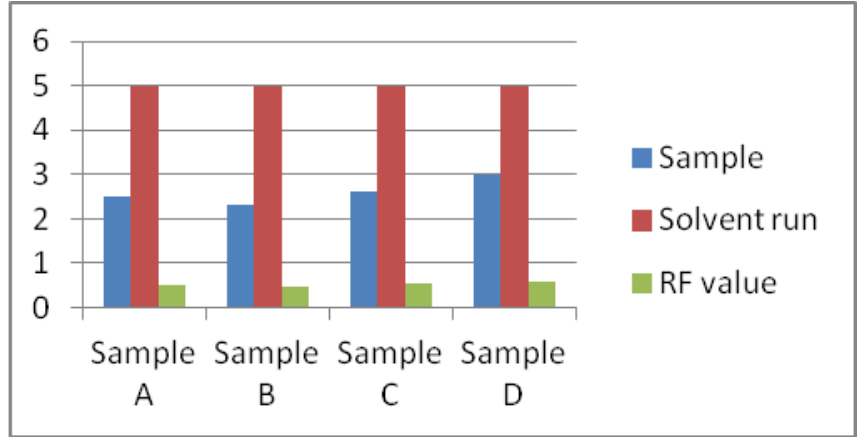

Fig.4 TLC of steroids

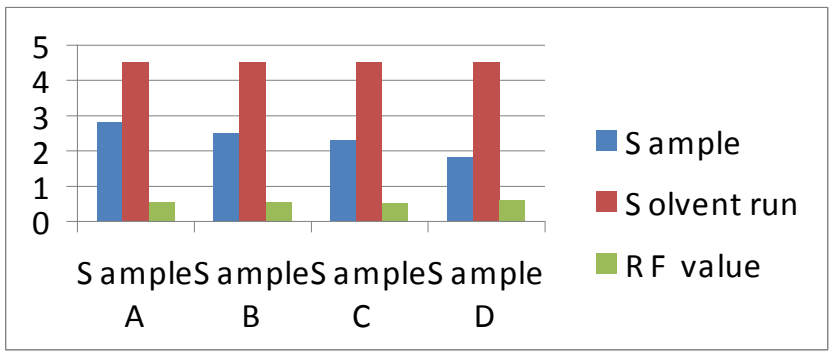

Fig.5 TLC of Glycosides

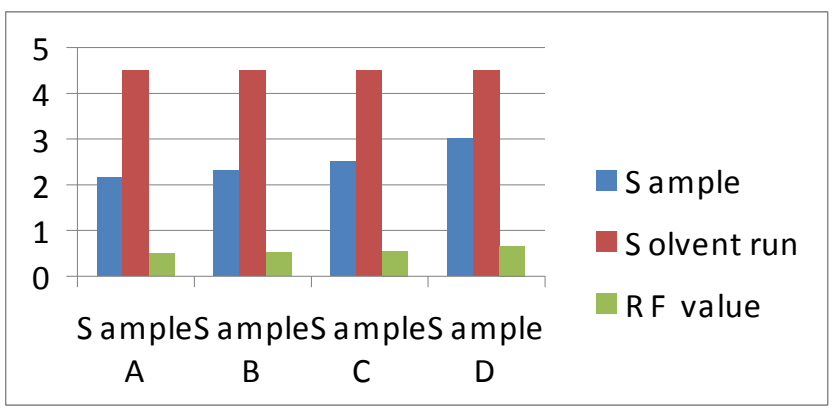

Alkaloids, flavonoids, phenols, steroids, glycosides, tannin, steroid, lignin and terpenoid were separated from Simarouba glauca through Thin Layer Chromatography (TLC). From this analysis different RF values of eight different secondary metabolites were obtained. So, the present study shows that the tree has a presence of various phytochemicals and metabolites which has a role in the insectidal, antimicrobial, pharmacological, physiological, clinical, phytoremediation properties. It could be used for the production of different plant based medicines and could be used in the production of plant based medicines. But also there is ample need to work on to improve the quality and quantity of these value added products for pharmaceutical formulation development. Marker based selection can be done to achieve maximum therapeutic activity of specific plant components. Same type of research and review papers have been published on 
Tribulus terrestris (Verma et al., 2009), Oxalis corniculata (Verma, 2009), Solanum nigrum (Kumar et al., 2012), Cuscuta reflexa (Kumar et al, 2012), Acorus calamus (Kumar et al., 2014), Simarouba Glauca (Kumar et al., 2014), Murraya koeingii (Kumar et al., 2015) and Catharanthus roseus (Kumar et al., 2015). These became popular articles for further investigations on particular medicinal herbs.

\section{Acknowledgement}

Authors are thankful to Dr. BK Tyagi, Executive Director, Shri Ram Group of Colleges, Muzaffarnagar for providing the internet facility and Departmental Library facilities. Authors are also thankful to the Librarian, providing the necessary valuable books, thesis, research journal and articles etc.

\section{References}

Armour, R.P. 1959. Investigations on Simarouba glauca DC. InE1 Salvador. Economic Bot., 13: 41-66.

Azam, M., Waris, A., Nahar, N. 2005. Prospects and potential of fatty acid methyl esters of some non-traditional seed oils for use as biodiesel in India. Biomass Bioenergy, 29: 293-302.

Chhetri, P.H., Nisha, S.Y., Jyoti, S., Anupa, K.C., Mansoor, S., Panna, T. 2008. Phytochemical and antimicrobial evaluation of some medicinal plants of Nepal, Kathmandu. Univ. J. Sci. Eng. Technol., 1(5): 49-54.

Devkota, K.P., Wilson, J.A., Henrich, C.J., McMohan, J.B., Reily, K.M., Beutler, J.A. 2014. Compunds from Simaroba beteroana which inhibit proliferartion of Nf1-defective cancer cells. phytochem lett., 7: 4245.
Dey, P.M., Harbour, J.P. 1987. Methods in plant biochemistry. Academic Press, London.

Doss, A. 2009. Preliminary phytochemical screening of some Indian medicinal plants. Ancient Sci life, 29(2): 12-16.

Edeoga, H.O., Okwu, D.E., Mbaebie, B.O. 2005. Phytochemical constituents of some Nigerian medicinal plants. Afr. J. Biotechnol., (7): 485-688.

Evans, W.C. 1989. Pharmacognosy, $13^{\text {th }}$ Ed, Balliere-Tindall, London.

Ghosh, P.C., Larrahondo, J.E., LeQuesne, P.W., Raffaur, R.F. 1977. Antitumour Plants.IV. Constituents of Simarouba versicolor. Lloydia, 40(4): 364-369.

Jena, P.C., Raheman, H., Prasanna, K.G.V., Machavran, R. 2010. Biodiesel production from mixture of Mahua and Simarouba oils with high free fatty acids. Biomass and Bioenergy, 34: 1108-1116.

Jeyarani, T., Reddy, S.Y. 2001. Cocoa butter extender from Simarouba glauca fat. J. Amer. Oil Chem. Soc., 78(3): 271276.

Joshi, S., Joshi, S. 2002. Oil tree-Laxmitaru glauca. University of Agricultural Sciences, Bangalore and Indian Council of Agricultural Research, New Delhi, India.

Krishnaiah, D., Devi, T., Bono, A., Sarbatly, R. 2009. Study on phytochemical constituents of six Malasian medicinal plants. J. Med. Plants Res., 3(2): 67-72.

Kumar, A., Kumar, P., Kumar, V., Kumar, M. 2014. Traditional uses of wetland medicinal plant Acorus calamus: review and prospective. Res. Ref., 17: 37-67.

Kumar, A., Malik, R., Giri, P., Parveen, N., Shweta. 2015. Up-to-date review on therapeutic interior of catharanthus roseus; for anticancer and 
antidiabetic activities. J. Phytomed., 1(1): 1-13.

Kumar, A., Niketa, Rani, S., Sagwal, S. 2012. An absolute review on Oxalis corniculata. IJP, 1(12): 100-122.

Kumar, A., Rani, S., Niketa, Sagwal, S. 2012. Recent review on plant moleculer biology, Phytophysiology Phytochemistry and ethanopharmacology of Cuscuta reflexa Roxb. (A parasitic plant). Int. Res. J. Pharm., 3(7): 30-38.

Kumar, A., Sagwal, S., Niketa, Sapna Rani. 2012. An apdated review on moleculer genetics Phytochemistry pharmacology and physiology of black nightshade (Solanum nigrum)'. Int. J. Pharma. Sci. Res., 3(9): 29562977.

Kumar, A., Shweta, Neetu, Giri, P. 2015. Advance Review On Phytochemistry, Pharmacology, Antimicrobial, And Clinical Activities Of An Antidiabetic Plant (Murraya Koeingii L.) IJRR, 3(1): 60-87.

Kumar, A., Tyagi, G., Sharma, S., Kumar, V., Pundir, R. 2014. Current Review on Biotechnological and Pharmacological Investigations of Simarouba Glauca-an oil Yielding Plant'. Int. J. Pharmacognosy, 1(12): 100-122.

Mabry, T.J., Markham, K.R., Thomas, M.B. 1970. The systemic identification of flavonoids. Springer-Verlag, Berlin Heidelberg, New York. 1-102.
Mallikharjuna, L.N., Rajanna, Y.N., Seetharam, S. 2007. Phytochemical studies of Strychnos potatorum L.FA medicinal plant. E-Journal of Chem., 4(4): 510-518.

Neelavathi, A., Sekhar, K.B., Babu,, C.R., Jayaveera, K.N. 2004. Removal of toxicCr(VI) by the adsorption of activated carbon prepared from Simarouba shells. J. Environ. Sci. Eng., 46(2): 137-42.

Rajasekariah, G.R., Parab, P.B., Chandrashekhar, R., Deshpande, L., Subrahmanyam, D.1991. Pattern of Wuchereria bancrofti microfilaraemia in young and adolescent school children in Bassein,India an endemic area for lymphatic filariasis. Ann. Trop. Med. Parasitol., 85(6): 663-665.

Rhoades, C.C., Sanford, J.R.L., Clark, D.B. 1994. Gender dependent influences on soil phosphorous by the dioecious low land tropical tree Simarouba amara Biotropica. 26(4): 362-368.

Singh, B., Gupta, D.K., Chandan, B.K. 2001. Adaptogenic Activity of a glycol-peptico-lipid fraction from the alcoholic extract of Trichopus zeylanicus Gaertn. Phytomedicine, 84(5): 510-512.

Verma, N., Kumar, A., M.I.S. Saggoo, Gokharu. 2009. (Tribulus terrestris L.) A traditionally important wild medicinal herb of waste lands. $J$. Plant Dev. Sci., 1(3\&4): 179-187.

\section{How to cite this article:}

Ashwani Kumar, Vishwa Rawat, Amardeep and Vikas Kumar. 2016. Comparative Evaluation of Phytochemicals in Methanolic and Ethanolic Leaf Extracts of Anticancer Paradise Tree Simarouba glauca DC. Int.J.Curr.Microbiol.App.Sci. 5(6): 679-686. doi: http://dx.doi.org/10.20546/ijcmas.2016.506.074 